\title{
World Bank, IMF and Human Rights: Conference held at Tilburg University, 11-13 October, 2001
}

By Christina Gille and Stefanie Ricarda Roos

Suggested Citation: Christina Gille and Stefanie Ricarda Roos, World Bank, IMF and Human Rights: Conference held at Tilburg University, 11-13 October, 2001, 3 German Law Journal (2002), available at http://www.germanlawjournal.com/index.php?pagelD=11\&artID=131

It is important to recognize when there has been a defining moment for the international promotion and protection of human rights. One such moment, I believe, was when the World Bank Group recognized that it had an express role to play in the promotion and protection of human rights. (1)

[1] The twin Bretton Woods institutions, comprising the World Bank (2) and the International Monetary Fund (IMF), have in the past decades come under increased and intensified scrutiny, in particular as regards the social and environmental consequences of their activities. International awareness and criticism of the negative impacts of Bank and Fund projects grew during a period of time in which the concept of development has been entirely reconceptualized: Development is no longer measured in economic terms only, but understood as "a comprehensive economic, social, cultural and political process, which aims at the constant improvement of the well-being of the entire population and of all individuals." (3)

[2] According to this new paradigm, human rights are considered to be the end purpose of development. In tune with this new approach, various United Nations bodies, in particular UN treaty bodies, such as the Committee on Economic, Social and Cultural Rights have in recent years repeatedly declared that "the realms of trade, finance and investment are in no way exempt from human rights obligations and principles, and that the international organizations with specific responsibilities in these areas should play a positive and constructive role in relation to human rights." (4) The history of the World Bank's actions in the area of human rights reveals an inconsistent pattern of practice. On the one hand, the World Bank continues to approve loans to countries with well-known poor human rights records; on the other hand, the Bank contributes directly to the fulfillment of many, particularly economic, social, and cultural, human rights obligations through its support of, inter alia, primary education, health care and nutrition, sanitation, and housing projects.

[3] The goal of last fall's Conference entitled "World Bank, IMF and Human Rights" was to come up with "a balanced and objective overview and analysis of the relevant activities of both the World Bank and the IMF, in the context of international human rights law." (5) The Conference was held at Tilburg University, The Netherlands, from 11-13 October, 2001, and was jointly organized by: (a) the Institute for Globalization and Sustainable Development of Tilburg University (Globus); (6) (b) the Centre for Dignity and Rights of Cedar International, (7) based at the TMC Asser Institute for International Law, The Hague; and (c) the Netherlands Research School of Human Rights, which is composed of researchers working at the Universities of Maastricht, Rotterdam, Tilburg and Utrecht, as well as at the TMC Asser Institute.

[4] One of the great assets of the Tilburg Conference undoubtedly was that it brought together both scholars and practitioners endeavoring to find, not only theoretical, but also practical answers to such pressing questions, most particularly, whether and to what extent the World Bank and the IMF can and should effectively integrate human rights concerns in their policies and activities. While, unfortunately, the conference organizers were unable to find a competent representative of the IMF to participate in the conference, the World Bank was represented by the highranking Dr. Alfredo Sfeir-Younis, Special Representative of the President of the World Bank to the United Nations and the World Trade Organization (WTO) and Head of the Geneva Office of the World Bank. Dr. Sfeir-Younis serves as the institutional focal point at the World Bank with respect to human rights issues.

\section{First Day of the Conference}

[5] In his opening presentation, entitled "Human Rights and Economic Development: Can They Be

Reconciled?", Dr. Sfeir-Younis set the stage for the following presentations and discussions by presenting his ideas regarding how human rights could be "mainstreamed" into economic development. According to Dr. Sfeir-Younis, who is an environmental economist by training, the revived attention being paid to the normative dimensions of economics and financial processes, both in the formulation of policies and in the design and implementation of development activities, was the result of what he described as "a major revolution in value systems." Accordingly, his most important message, running like a thread through his entire presentation, was that any mainstreaming of human rights into economic development required focus on issues of values and beliefs, i.e., to seek to understand the value systems currently in existence as well as the professions influencing decision-making.

[6] In his presentation on "Self-Regulation", Dr. Koen de Feyter (8), Lecturer in Law at the Maastricht University, put 
a special emphasis on the contradictory actual position of the World Bank concerning the respect of human rights in its activities: on the one hand, the Bank's position is characterized by the unsystematic adoption of internal rules and strategies touching upon human rights issues; on the other hand, the Bank refuses, at the same time, to recognize that it is bound by a formal obligation to respect human rights. From the Bank's point of view, the final responsibility for the protection of human rights rests with the states. Looking at the existing internal rules (Operational Policies et al.) of the World Bank, Dr. de Feyter made the observation that these Ops go much further concerning the respect of international obligations to protect the environment. For example, the environmental assessment provided for in $O P$ 4.01 expressly conditions the support for projects on the non-violation of the country's obligations stemming from international environmental treaties and agreements. The failure to adopt parallel human rights preconditions for the Bank's financing of projects seems to be the outcome, not of legal constraints, but of a simple policy choice.

[7] The Inspection Panel, which was established by the World Bank in 1993, as an independent mechanism of control, is charged with to investigating the Bank's compliance with its own binding, internal rules. The Panel exercises its authority to investigate at the request of a party that demonstrates that its rights or interests have been or are likely to be affected by the Bank's (in)activity. According to Dr. de Feyter, the Panel merely constitutes a weak internal accountability mechanism. First, the Panel is only competent to examine the Bank's and not the Borrower's conduct; it cannot treat general international law issues. Second, the Board of Executive Directors decides whether investigations by the Panel should be initiated and whether the Panel's recommended measures are to be adopted. Third, due to the fact that the Board only decides whether concrete measures and not whether the Panel's complete reports should be adopted, the reports of the Panel cannot lead to the creation of controlling precedent.

[8] Trying to find innovative ways to establish an external mechanism for accountability over the Bank, Dr. de Feyter explored the possibility of granting affected persons the use national tort law against human rights violations committed by the Bank. The Bank's internal rules could be taken into consideration for the determination of the standard of care expected from the Bank (in determining questions of negligence). Dr. De Feyter proposed a restrictive interpretation of art. VII sect. 3 of the IBRD Articles of Agreement on the Bank's jurisdictional immunity covering only claims from member states and private claims derived from such claims.

[9] To find new ways to protect and promote of human rights issues in the activities of the IFIs, the organizers of the conference chose not only an inter-disciplinary approach to the topic, but also to include representatives of "Civil Society" in the discussion and the process of elaboration of the guidelines. This had the advantage of combining scholars' theoretical work with practical input from those working directly in the human rights field. Representing the "Minority Rights Group", based in London, Corinne Lennox gave some insight on the work of NGOs to promote and protect human rights and gave a "Report on the International Seminar on Cooperation for the Better Protection of the Rights of Minorities, Durban/SA September 2001". The Seminar had been organized in conjunction with the World Conference against Racism held in Durban, South Africa, in September, 2001. The aim of the seminar had been to elaborate recommendations addressing states as well as other actors in development processes, including the international financial institutions, to ensure that development policies incorporate the needs and concerns of minorities and indigenous peoples through their free, full and informed participation in all stages of the development process. (9)

[10] Prof. Dr. Bas de Gaay Fortman (10) focused his presentation, entitled "Poverty as Human Rights Deficit Some Implications for the International Financial Institutions", on the evolution of the notion of "poverty" over the last decades. Today, he explained, "poverty" is understood as a multi-layered phenomenon, characterized not only by economic aspects but also by the lack of power, participation and effective jurisdictional protection of the affected persons. (11) A "right" is defined as a recognized interest protected by law (von Jhering) but the poor, Prof. de Gaay Fortman noted, generally live under conditions not providing effective legal protection of their interests. Concerning human rights, especially esc-rights, he found noteworthy that the declaration of rights often precedes the effective enjoyment of the rights by the concerned persons. According to Prof. de Gaay Fortman, strategies to reduce poverty should, therefore, focus on the: (a) empowerment of affected persons, (b) the elimination of anti-poor varieties of economic growth, and (c) on the implementation of human rights by the recognition of external accountability by institutions and persons that might violate human rights in the exercise of power. Concerning the World Bank, Prof. de Gaay Fortman argued that the Bank is obligated to recognize its duties concerning the respect of human rights and to commit itself to external accountability to legitimize its activities.

\section{Second Day of the Conference}

[11] Dr. Sigrun I. Skogly, Lecturer in Law at Lancaster University Law School, ventured to answer the core legal question of the Conference, i.e. the question if and to what extent multilateral financial institutions (MFIs) are obliged and free to respect human rights in their activities. (12) In her presentation entitled "The Human Rights Obligations of the World Bank and the IMF", Dr. Skogly first analyzed the legal foundations for holding the two institutions to human rights obligations, proceeding on the assumption that human rights were part of a larger framework of 
international law in which all legal actors, including the two main multilateral financial institutions, operate. In the second part of her presentation, Dr. Skogly analyzed what was to be understood by "human rights obligations," challenging the traditional separation between civil and political human rights on the one hand, and economic, social, and cultural rights, on the other hand. In her opinion, the division of obligations into three levels, i.e. the obligation to respect, protect, and fulfill (first developed by Asbjorn Eide in his study as a Special Rapporteur on the Right to Adequate Food) should be followed instead. Dr. Skogly came to the conclusion that, whereas the obligation to respect human rights was today accepted by the World Bank's Legal Department, the latter still refuted that the Bank also had an obligation to promote human rights.

[12] Prof. Dr. Jan Wouters (13) explored, in his report on "The Role of Corporations in Fulfilling the Tasks of World Bank and IMF", the ways in which private corporations are involved in the activities of the World Bank and the IMF, as well as the legal nature of these relationships. Concerning the question whether the private partners of the World Bank and the IMF are bound to respect human rights norms when fulfilling tasks of these institutions, Wouters underlined the binding effect of customary international human rights norms on the IFIs and suggested further reflection on a possible horizontal effect of human rights (binding private actors directly), on a possible shift of (customary) human rights obligations from the IFIs to their private partners due to the characterization of their relationship as one between a principal (the IFIs) and an agent (the private corporations acting on behalf of the IFIs) or on the idea that the private actor might partially become an actor on the international level in the fulfillment of its tasks. Viewed in this way, IFIs and their private partners would be bound to respect (customary) international human rights norms.

[13] In the quest to achieve the respect of human rights, one cannot leave aside the work of the specialized UN organs in the human rights field. One important issue might be to clarify the "Relations Between the UN Committee on Economic, Social and Cultural Rights and the International Financial Institutions". This was the aim of Prof. Paul Hunt's contribution to the conference. Prof. Hunt is Rapporteur of the UN Committee on Economic, Social and Cultural Rights and Director of the Human Rights Center, University of Essex, England. First, he underlined the increased activity of the UN Committee on esc-rights in the last years and the adoption of three General Comments on substantial rights in 1999 and 2000: on the right to food, the right to education and the right to health. These General Comments show, according to Hunt, some particular jurisprudential features. First, they use the three-fold approach to human rights obligations that distinguishes between an obligation to respect, an obligation to protect and an obligation to fulfill human rights. Second, they use the concept of "core obligations" that apply to all states irrespective of their actual stage of economic development. Third, they contain concrete examples of violations of the concerned esc-right; giving some hints as to how indicators and benchmarks should be applied in relation to escrights. Fourth, they expressly address member states' obligations to take due account of esc-rights in their activities as members of international institutions although they do not address direct obligations of non-state actors due to the lack of consensus on this point in the Committee. Concerning the relationship between the Committee and the international financial institutions, Hunt raised the idea that member states might use the Covenant and the obligations imposed by the Covenant as an international shield to protect their population against international projects and policies that might negatively affect the rights of their population. Hunt also suggested an in depth discussion of the question whether or not the flow of data and information from the World Bank and the IMF to the Committee should be increased to assist the Committee in its duty to report on the situation in the member states.

[14] That the Conference organizers had endeavored to make the Tilburg Conference truly inter-disciplinary. This was again demonstrated by Dr. Berma Klein Goldewijk's presentation on "Shifting Power Dynamics, Globalisation and its Critics: The Implementation of Economic, Social and Cultural Rights". The program director at Cedar International examined the anti-globalists' criticism of the World Bank and the IMF from the point of view of political science and philosophy. Dr. Klein Goldewijk was primarily interested in analyzing the power dynamics that are at the bottom of this critique. In the second part of her presentation, she discussed the question what impact the emergence of new civil society instruments and strategies a part of a broader multi-actor approach might have for the implementation of economic, social, and cultural rights.

[15] An unfortunate consequence of the events of September 11, was that only one speaker from the American continents was present at the Tilburg Conference, i.e. Dr. Camilo Perez-Bustillo, Research Professor of Law and Media Studies at ITESM, Mexico. In his presentation entitled "Towards International Poverty Law. The World Bank, Human Rights, and Indigenous Peoples in Latin America", Prof. Perez-Bustillo undertook to answer the question to what extent World Bank policies and practices are consistent or conflict with the most relevant trends in international, regional, and domestic law regarding the rights of indigenous peoples. According to Prof. Perez-Bustillo, the current international legal structure regarding those rights can only be assessed through an inter-active analysis including a comparison of the recognition of indigenous rights in various national constitutions, for instance those of some Latin American countries such as Columbia, Guatemala, Mexico, and Ecuador. (14)

[16] As had been the case for most of the previous speakers at the Conference, the special merit of Prof. Perez- 
Bustillo's presentation was his innovative approach to the issue of the relationship between the World Bank and Human Rights. Two of Prof. Perez-Bustillo's suggestions best illustrate this approach. First, he proposed that a complete assessment of the implication of World Bank policies and practices for international human rights compliance, practice, and scholarship would be best served by the development of a new paradigm that he defined as that of "international poverty law," i.e. the law that refers to a group in society which is characterized by patterns of marginalization and exclusion. Second, referring to the Inter-American Court of Human Rights' most recent decision (rendered August 31, 2001) concerning, inter alia, government recognition and effective protection of indigenous peoples' rights of ownership, (15) Prof. Perez-Bustillo put the question up for discussion whether the World Bank's failure to recognize its own policies could - in itself - constitute a violation of international human rights law for which the Bank could be held responsible. With that, Prof. Perez-Bustillo, too, arrived at one of the Conference's core questions, namely the question of the World Bank's legal obligations in the field of human rights.

[17] The conference was only one first step in a broader process, the ultimate aim of which is to establish guidelines or guiding principles on how the World Bank and the IMF (as well as their "owners") may take due account of human rights in their activities. This first step consisted in the presentation and discussion of the nine papers covering various aspects of the topic and the production, in the end, of the first draft of the guidelines/guiding principles on the basis of the presentations and discussions. The first draft of the guidelines/guiding principles addressed the "owners" of the World Bank and the IMF as well as both institutions themselves. The draft was divided into five sections: human rights obligations; linking legal obligations in the field of human rights to economic and political realities; the role of the private sector; assessment of human rights violations; and a process approach (focusing on processes of the consensus building and the exercise of political power).

[18] The follow-up to the Conference will consist of the issuance of a second draft of the presented papers sometime this month, the collection of comments on the papers and publication of a final draft of the papers by March, 2002. At the same time, a second draft of the guidelines/guiding principles based on the discussions held in October, 2001, will take place by the end of this month, followed by the collection of commentaries on the second draft and the elaboration of a third draft by April/May, 2002. The third draft of the guidelines/guiding principles will be submitted to a final discussion by the participants in April/May, 2002. Finally, the papers and the guidelines/guiding principles will be published in the summer of 2002.

(1) Mary Robinson, United Nations High Commissioner for Human Rights, "Foreword" in: The World Bank, Development and Human Rights: The Role of the World Bank, 1998, p. 7.

(2) The World Bank Group consists of the International Bank for Reconstruction and Development (IBRD); the International Development Association (IDA); the International Finance Corporation (IFC); the Multilateral Investment Guarantee Agency (MIGA); and the International Centre for Settlement and Investment Disputes (ICSID).

(3) Cf., e.g., the Declaration on the Right to Development, adopted by General Assembly resolution $41 / 128$ of 4 December 1986, see http://www.unhchr.ch/html/menu3/b/74.htm.

(4) See, e.g., Sub-Commission resolution 1998/12, United Nations, Economic and Social Council, Sub-Commission on Prevention of Discrimination and Protection of Minorities, Human rights as the primary objective of trade, investment and financial policy, UN Doc. E/CN.4/Sub.2/Res/1998/12, 20 August 1998.

(5) 'World Bank, IMF and Human Rights', Working Document, September 2001 (unpublished).

(6) Globus is a center for multi-disciplinary research in the areas of globalization and sustainable development founded in 1998 as an inter-faculty institute at Tilburg University (The Netherlands). Website: http://globus.kub.nl.

(7) Cedar International is an International Forum for the Implementation of Economic, Social and Cultural Rights, with a facilitating Centre for Dignity and Rights.

(8) De Feyter has published in 2001 a book on „World development law: sharing responsibility for development".

(9) See http://www.minorityrights.org/.

(10) Professor of Political Economy, Institute of Social Studies, The Hague, and Professor of Political Economy of Human Rights, Utrecht University.

(11) See also, D. Dollar, Globalisation, Inequality, and Poverty since 1980 (2001), available at 
http://econ.worldbank.org/files/2944_globalization-inequality-and-poverty.pdf; and the most recent study of the World Bank, Globalization, Growth and Poverty: Building an Inclusive World Economy (2001), description available at http://www.worldbank.org/developmentnews/stories/html/120601a.htm.

(12) For an in-depth analysis of this question, see Skogly's recently published book, Sigrun Skogly, The Human Rights Obligations of the World Bank and the International Monetary Fund, London, Cavendish, 2001.

(13) Professor of International Law, Leuven University.

(14) Prof. Perez-Bustillo refers to the recent wave of constitutional recognition of indigenous rights as "multicultural constitutionalism."

(15) Caso de la Comunidad Mayagna (Sumo) Awas Tingnis vs. Nicaragua (Case of the Indigenous Mayagna Community of Awas Tingni), the full Spanish text and excerpts from the English text and an English summary are available on-line through the web-pages of the Indian Law Resource Center, at http://www.indianlaw.org/awas_tingni_sentencia_de_la_co.htm. 